\title{
American doctors expect to save money under new US tax law
}

\author{
— Cite as: CMAJ 2018 February 5;190:E145-6. doi: 10.1503/cmaj.109-5551
}

Posted on cmajnews.com on Jan. 15, 2018.

$\mathrm{T}$ ax reforms introduced by the Canadian government last year proved unpopular with many physicians, who viewed the changes as unfair and damaging to their livelihoods. The United States also altered its tax system. Unlike in Canada, however, the changes in the US may prove favourable to physicians.

In December, the US Senate approved a tax bill that will make "the most drastic changes to the US tax code since 1986." The bill lowers the top corporate tax rate from $35 \%$ to $21 \%$, and the highest tax rate for individuals will drop from $39.6 \%$ to $37 \%$. The bill is estimated to eliminate $\$ 1.5$ trillion in tax revenue, and many economists suggest high-earners will benefit the most - which means physicians should see major tax reductions.

Indeed, according to Business Insider, physician income in the US is generally above $\$ 200,000$ and all specialties will see tax savings, some more than others. Of the medical specialists considered, Business Insider estimated tax savings ranging from 4.4\% (anesthesiologists; average salary: $\$ 269,600)$ to $11.5 \%$ (pediatricians; average salary: $\$ 184,240)$. A family doctor, with an average income of $\$ 200,810$, would receive an $8.9 \%$ tax cut.

An anesthesiologist who runs a personalfinance blog called Physician on Fire estimated he would save $\$ 8000$ in 2018 because of the new tax legislation. Earnings up to $\$ 315,000$ now fall in a $24 \%$ tax bracket, whereas previously a $33 \%$ tax bracket began at $\$ 233,000$ and a $28 \%$ bracket at $\$ 153,000$. "That's a huge difference," wrote the physician, who said he attained financial independence at age 39 after practising for nine years.

However, another physician with a personal-finance blog (Passive Income M.D.) predicted that his taxes would increase. "My wife and I are both physicians in higher-paying specialties," he wrote. According to his calculations, very highearning physicians (annual earnings exceeding $\$ 600,000$ ) will pay more in taxes despite a reduction of the highest individual tax rate because certain deductions are phased out at that level of income. could affect physicians, the biggest potential benefit to US physicians will be a reduction in taxes on "pass-through" income. Self-employed doctors are soleproprietors and their earnings are "passed through" the business to the individual as personal income. That income is then taxed at the business owner's individual tax rate rather than a corporate tax rate.

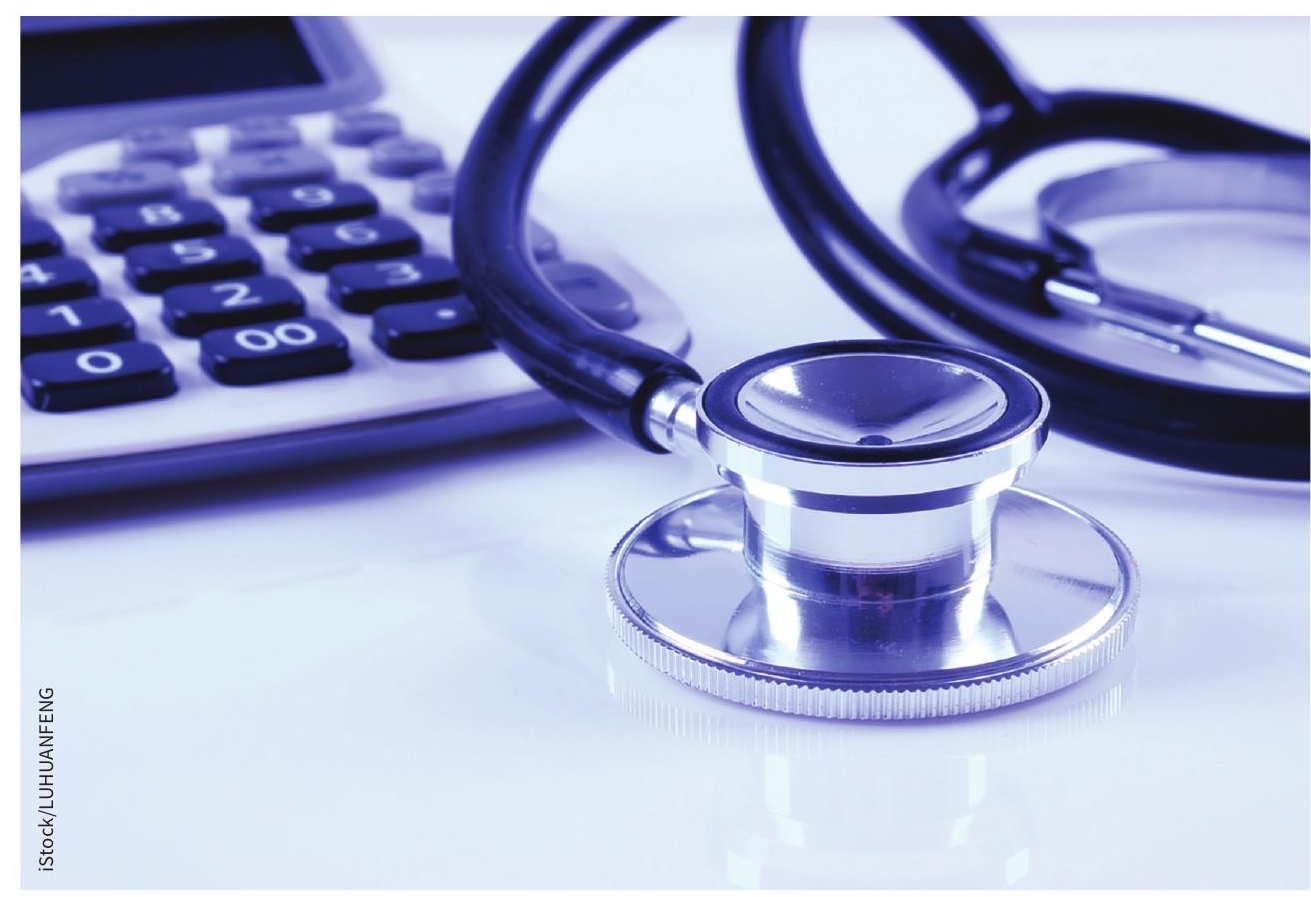

American physicians aren't sure exactly how they will be affected by new US tax legislation, but many expect to pay less in taxes.

"I didn't write this to try to garner any sympathy for the high-income physician," the author added. "It's simply to report the repercussions of the new tax bill and how it may affect my family and many other physicians, lawyers, and other highincome service professionals."

According to a detailed breakdown on MedScape of how the new tax legislation
Under the new legislation, some owners of pass-through businesses will be able to deduct $20 \%$ of their revenue from their taxable income. The savings would be a "huge boon" for self-employed physicians, Dr. James Dahle, founder of The White Coat Investor, told Medscape, adding that it "will drive docs to be more likely to be self-employed." 
Michael Zhuang, founder of a wealth management firm specializing in helping physicians build wealth, recognized the potential of the changes to pass-through earnings to save money for his clients. A doctor earning $\$ 500,000$ from a hospital would be wise to set up a corporation and have the hospital pay the business instead of receiving income as salary, noted Zhuang, who added that "you can bet that I will help my physician clients take advantage."
As is often the case with tax law, however, there are many details and it isn't always easy to determine who qualifies for any given deduction. On a forum on The White Coat Investor website, several physicians discussed the pass-through deduction. Among the many factors discussed that could affect physician taxes include whether they are married, whether they have children, if they earn more than $\$ 315,000$, if they earn more than $\$ 415,000$, and if they earn additional income from sources outside their medical practices. There are also mentions of "S-corp singlemember LLCs" and "W2 wages" and "phaseouts" and "MFJ limits" and separating "nonservice business" from "service business."

"I feel so dumb," wrote one forum member. "I thought I had a handle on it but am more confused than ever."

Roger Collier, CMAJ 